Brief Report

\title{
Demographic Transitions and Socioeconomic Development in Italy, 1862-2009: A Brief Overview
}

\author{
Luca Salvati ${ }^{1}$, Margherita Carlucci ${ }^{2}$, Pere Serra ${ }^{3}$ (I) and Ilaria Zambon ${ }^{4, *}$ \\ 1 Council for Agricultural Research and Economics (CREA), Viale Santa Margherita 80, I-52100 Arezzo, Italy; \\ luca.salvati@crea.gov.it \\ 2 Department of Social and Economic Sciences, Sapienza University of Rome, Piazzale A. Moro 5, \\ I-00185 Rome, Italy; margherita.carlucci@uniroma1.it \\ 3 Department of Geography, Autonomous University of Barcelona, Building B, Campus UAB, \\ ES-08193 Bellaterra (Cerdanyola del Vallès), Barcelona, Spain; pere.serra@uab.cat \\ 4 Department of Agricultural and Forestry Sciences (DAFNE), Tuscia University, Via San Camillo de Lellis, \\ I-01100 Viterbo, Italy \\ * Correspondence: ilaria.zambon@unitus.it
}

Received: 28 November 2018; Accepted: 26 December 2018; Published: 6 January 2019

\begin{abstract}
The present study investigates long-term population dynamics in Italy, 1862-2009, in light of Demographic Transitions (DTs). Under the assumption that DTs are multidimensional processes of change involving several aspects, including population structure and dynamics, an exploratory analysis was carried out in this study to verify temporal coherency of 15 indicators in Italy, identifying homogeneous time periods with distinct demographic characteristics. Indicators' trends were identified using a multivariate statistical approach. The results of this study allow empirical testing of the assumption of temporal coherence between different aspects of a long-term DT, distinguishing distinctive population dynamics and the differential impact on population structure over two centuries. After a relatively long period of demographic stability, the time window encompassing the two World Wars-approximately between 1921 and 1951—was identified as a primary turning point of population dynamics in Italy; a second turning point was estimated at the beginning of the 1970s. These time intervals may represent conditions of dynamic equilibrium between demographic and socioeconomic contexts, highlighting latent system transitions. The study concludes by outlining the importance of a more effective integration of demographic transition theories into a broader sustainability framework, and implementing a diachronic analysis of political, economic, and social forces associated with population dynamics in both advanced economies and emerging countries.
\end{abstract}

Keywords: population dynamics; socioeconomic structure; exploratory data analysis; Italy

\section{Introduction}

While latent interplays between population trends and socioeconomic development have been frequently investigated at global, regional, and local spatial scales [1-7], feedback relationships between demographic dynamics and broader dimensions of sustainability were more rarely outlined in recent studies. In this regard, socioeconomic development and population trends were disentangled within the framework of 'modernization' theory, hypothesizing a process-based transformation from traditional (underdeveloped) societies to modern (wealthy or emerging) societies with an advanced economy [8,9]. Focusing on basic conditions for industrialization and tertiarization [9], the theory of modernization emerged in the 1950s with the aim of explaining how industrial societies developed thanks to pivotal socio-political and cultural forces in the process of economic expansion. Modernization implies a generalized development within societies, including (but not restricted to) 
agricultural mechanization, massive industrialization, and the rapid shift towards (traditional and more advanced) services. The theory assumes that economic development depends primarily on technological import and several additional socio-political, productive, cultural, and institutional forces [10]. This theory postulates that societies and economies develop in (more or less) predictable stages through which they become increasingly complex, proceeding through increasingly non-linear transitions and more articulated transformations of their components [11]. These include-but are not limited to-increased levels of education and development of transport, logistic, communication, mass media, and international trade [12-14]. Urbanization (together with a shift from compact to more dispersed forms of urban expansion) and demographic change (population aging, fertility decline, and a progressive rearrangement of traditional families) are at the same time the cause and the effect of modernization [12]. In this regard, modernization and the consequent socioeconomic development are intimately linked with demographic transitions.

The concept of Demographic Transition (DT) refers to a continuous trend from high birth and death rates to low birth and death rates. This transition involves countries developing from pre-industrial to industrialized economic systems, with consequent socio-environmental changes identified and classified into four stages $[15,16]$. In the first stage, represented by a socioeconomic context typical of a pre-industrial society, birth and death rates are high and balanced [17]. In the second stage, death rates drop rapidly due to improvements in food supply and sanitation increasing life spans and reducing diseases. In the third stage, birth rates fall due to extended access to contraception, urbanization, reduced agricultural subsidies, wage increases, a rising status and education of women, containment of children's work, and an intense expansion of parental investments in the education of children, together with other minor social changes [18]. During the fourth stage-corresponding to contemporary societies-low birth rates and low death rates were extensively observed in advanced economies [19].

In Europe, a declining birth rate was observed for the first time in the late 19th century, especially in northern countries. By the late 20th century, birth and death rates leveled off at lower rates [18]. Fertility decline was usually greater among younger women, which suggests postponement rather than forgoing of births [20]. Substantial increases occurred in the percentage of young single adults who lived with their parents, contributing to a long-term trend toward intergenerational co-residence [21]. A slight decline in divorce and separation was also recorded in socioeconomic contexts characterized by high unemployment [22]. At the same time, changes in mortality rate and income inequalities resulted from a complex combination of socioeconomic factors [23-26].

Regulatory feedbacks between modernization (i.e., socioeconomic development) and socio-environmental issues are intimately linked with DTs. These transformations are particularly evident when studying the long-term evolution of a given country (or region) based on social, cultural, and economic indicators [15]. Due to the supposed relationship between socioeconomic development and population dynamics, a more comprehensive understanding of DTs may shed light on long-term economic changes and socio-ecological transformations [27]. In this line of thinking, interpretative models are rather generalizations that apply to a group of countries and that may not accurately describe each individual case. A multidimensional, diachronic analysis of the most relevant attributes of demographic transitions, and their coherence with external factors supposed to influence population dynamics, is thus particularly useful when ascertaining latent interactions between sustainable development and demographic patterns/processes.

Based on these premises, our analysis contributes to the assessment of latent aspects dealing with long-term socioeconomic development and population dynamics in a European country, under the assumption that DTs are complex processes characterized by multiple socioeconomic dimensions that lead to differentiated conditions advancing (or containing) sustainable development. Based on a multivariate analysis of demographic time series data representative of a relatively long time period (1862-2009), this study investigates multiple dimensions of the demographic transition in 
Italy, discussing long-term population-economy interplays and their impact on the inherent transition toward a truly sustainable development.

\section{Methodology}

The investigated area includes $301,330 \mathrm{~km}^{2}$ of Italian land. Demographic data considered in the present study refer to homogeneous geographical boundaries within the study period [28]. Population stock and vital statistics (births, deaths, and marriages), were used to detect recent demographic trends in Italy, which have been presented and discussed by [29] and [30]. A total of 15 demographic indicators derived from an extended set of country-scale time series annual data (1862-2009) released by the Italian National Institute of Statistics (ISTAT) were adopted with the aim to investigate DTs in Italy. Indicators were collected and harmonized from official data sources including population censuses and demographic registers.

Indicators adopted in this study assess multivariate aspects of demographic change, investigating population structure and dynamics [31-33]. Indicators include (i) natural balance (\%, per year, 'GRO'), (ii) migratory balance (\%, per year, 'MIG'), (iii) crude sex ratio (males-to-females, 'SEX'), (iv) crude birth rate (per 100 resident inhabitants, 'BIR'), (v) crude death rate (per 100 resident inhabitants, 'DEA'), (vi) stillbirth rate (per 100 births, 'STI'), (vii) infant mortality rate (deaths at age $0-4$ years per 100 resident inhabitants, 'INF'), (viii) non-legitimate (natural) children (births outside marriage per 100 births, 'NAT'), (ix) marriage rate (per 100 resident inhabitants, 'MAR'), (x) absolute difference between groom and bride age (years, 'BRI'), (xi) absolute difference between female and male median age (years, 'MER'), (xii) median age at death, males (years, 'AGE'), and, finally, (xiii) average age at marriage, groom (years, 'SPO'). Two supplementary indicators were considered: (xiv) total population (logarithm, 'POP'), and (xv) urbanization rate (\%, 'URB'). Indicators from (i) to (ix) assess demographic dynamics from different points of view (births, deaths, marriages); indicators from (x) to (xiii) quantify specific aspects of population structure. Indicators (xiv) and (xv) provide a context-based analysis of demographic trends, estimating total population density and urbanization processes over Italy.

Non-parametric correlations and a multivariate statistical approach incorporating Principal Component Analysis (PCA) and Hierarchical Clustering (HC) were applied to classify indicators into homogeneous groups, relating demographic dynamics to specific time intervals during the study period. The PCA is an exploratory statistical technique extensively used to identify and summarize latent factors possibly influencing the multivariate relationship among variables within a data set $[2,4,32]$. The PCA allows reduction of redundancy resulting from high levels of serial autocorrelation in the observed data, identifying the most relevant (independent) dimensions of Italy's DT. Selection of relevant components in a PCA is a subjective matter, since the technique is exploratory in its aims and not based on hypothesis testing. Using a correlation matrix as the input data matrix of a PCA, each input variable contributes with unitary variance to the overall matrix variance. Under the assumption that relevant components explain a higher variance than the variance of an individual variable, components with eigenvalue $>1$ were retained and analyzed in detail. Loading and score plot was extensively used to assess independent dimensions of DTs (the most characteristic indicators) in Italy. The PCA was supplemented with a hierarchical clustering (Euclidean distances, Ward's agglomeration rule) assessing similarity patterns over time in the selected demographic indicators. A visual inspection of dendrograms was adopted to classify indicators in consistent groups with similar demographic and socioeconomic features.

\section{Results}

\subsection{Descriptive Statistics}

Italy underwent a DT over the last two centuries reflected in specific trends of selected demographic indicators, as shown in Figure 1. A progressive decline of both fertility and mortality rates was observed (with a 30-year delay in long-term birth rate compared with death rate), respectively 
stabilizing to the lowest values in the early 1950s and the mid-1980s. The time period between the early 1950s and the mid-1980s was thus characterized by net population expansion; isolated spikes in time series of birth and death rates reflect demographic shocks caused by World Wars, as clearly evidenced in the time series of total population. Population growth decelerated in the early 1980s, remaining relatively stable since the 1990s. Migration balance was systematically negative (emigration > immigration) up to the early 1970s, with a progressive increase afterward and a structural peak recorded since the early 2000s. Urbanization rate increased continuously during the study period, accelerating since World War II. Other indicators displayed a temporal trend responding similarly to demographic shocks (World Wars) and long-term population trends. For instance, marriage rate declined progressively over time (with time series spikes corresponding to World Wars I and II) and stabilized to the lowest values in the mid-1980s. Infant mortality followed a similar time pattern, decreasing rapidly and linearly up to the mid-1950s and then declining more slowly up to a quasi-zero value recorded in the early 2000s. Crude birth and death rates display a distinct (linear) relationship over two time intervals (before and after World War II). Moreover, a separate short-term trend was observed for the time interval encompassing the two World Wars (1915-1945), confirming previous results as shown in Figure 2.
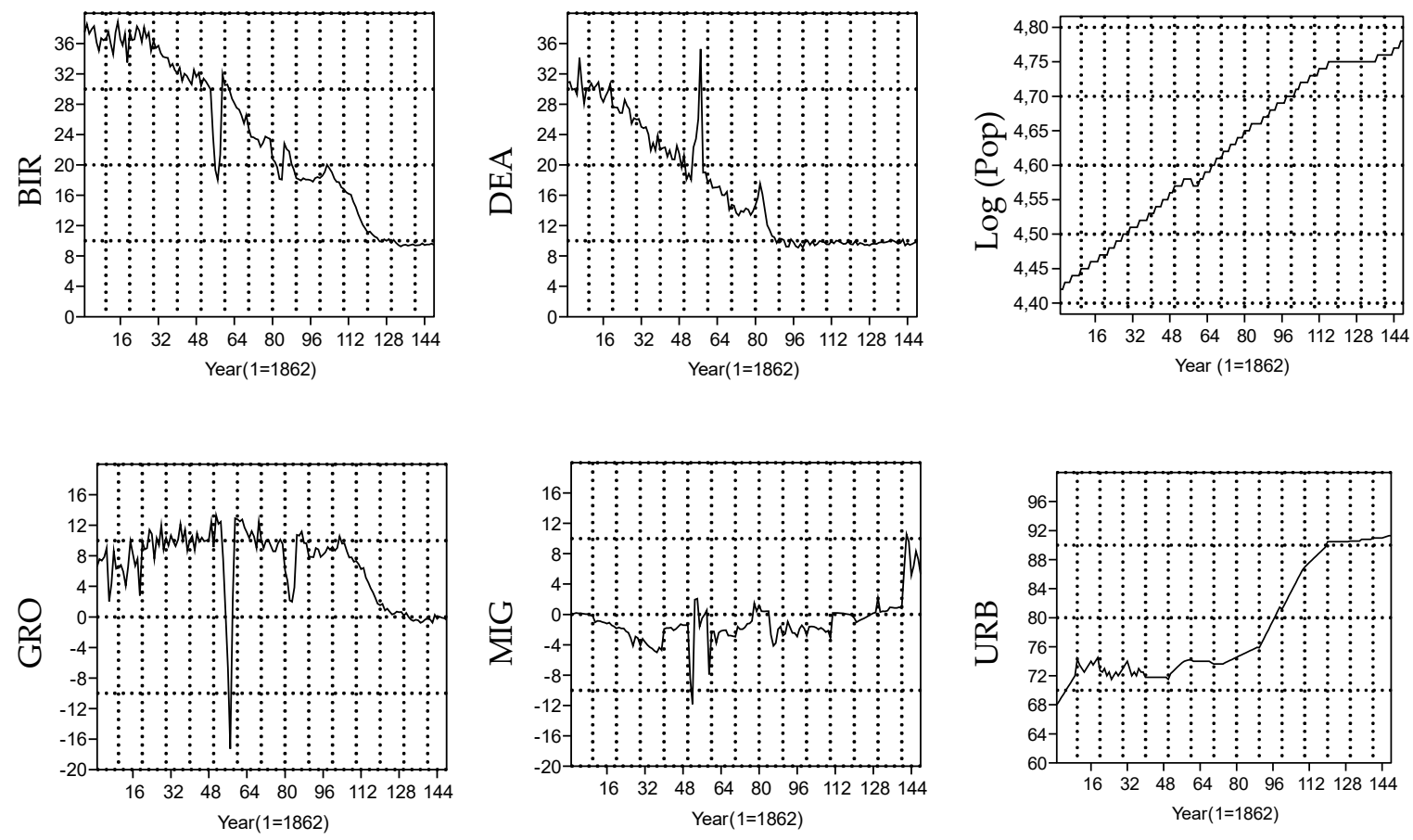

Figure 1. Trends over time in selected demographic indicators in Italy (1862-2009); BIR: Crude birth rate (per 100 resident inhabitants), DEA: Crude death rate (per 100 resident inhabitants), $\log ($ Pop): absolute population number (logarithm), GRO: natural balance (\% population growth per year), MIG: migratory balance (\% population growth per year), URB: urbanization rate $(\%)$; some time series spikes in the 1910s and the 1940s reflect World War I and World War II.

A descriptive analysis was carried out by computing average values and Coefficients of Variation (CV) for individual variables over two-time intervals as shown in Table 1, corresponding to a pre-war phase (1862-1945) and a more recent post-war phase (1946-2009). Some indicators increased substantially in the second time interval, displaying an increased variability over time. For instance, the migratory balance moved, on average, from negative values to slightly positive values, with a ten-fold increase of variability over time. A reverse pattern was observed for natural balance, crude birth rate, and stillbirth rate. Crude death rate clearly decreased over time in both average and variability over time. Taken together, population structure attributes showed moderate or more 
relevant increases over time; conversely, demographic dynamics attributes showed moderate decreases over time.

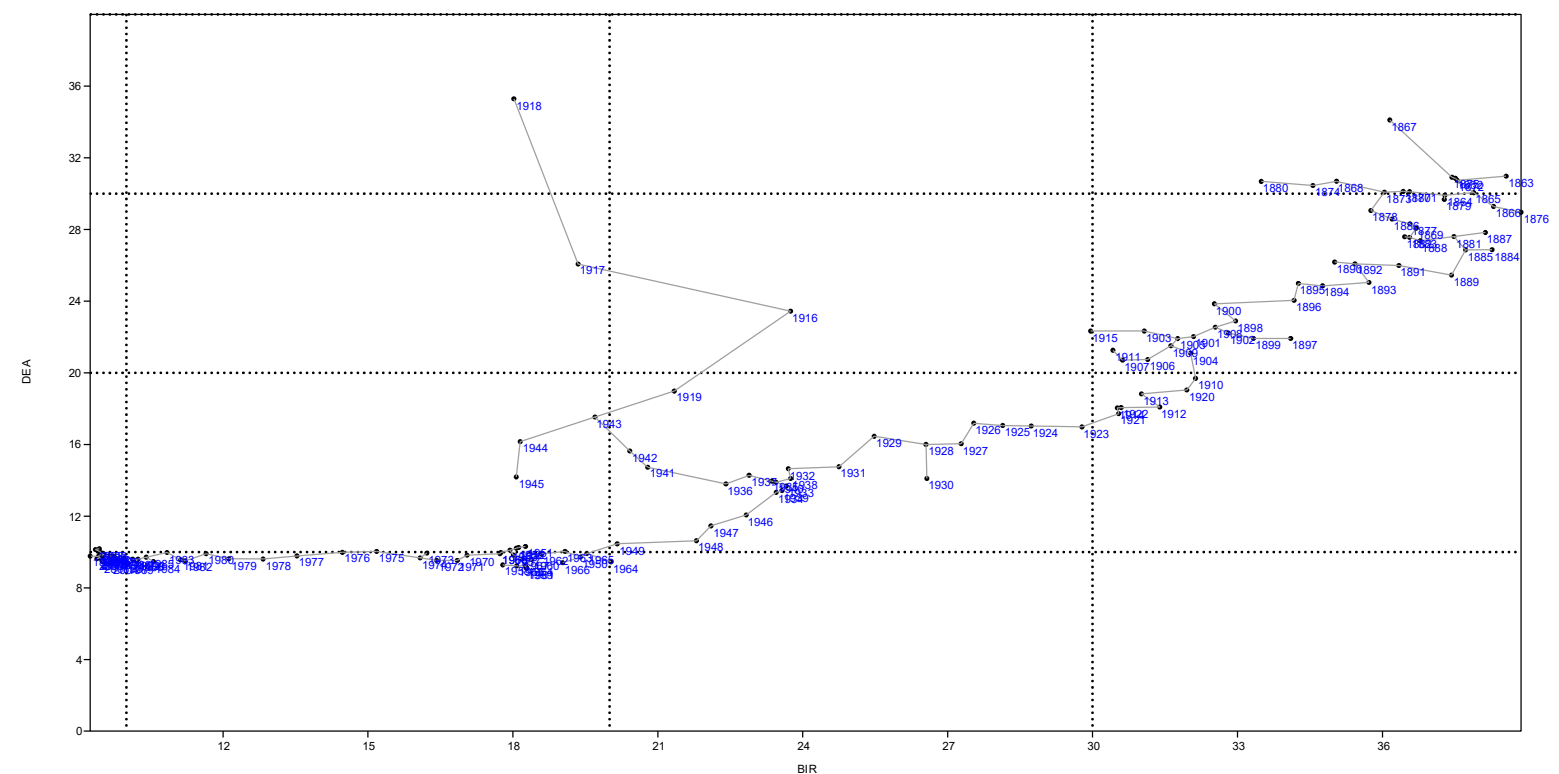

Figure 2. The relationship between crude birth rate (BIR) and crude death rate (DEA) in Italy, 1862-2009.

Table 1. Descriptive statistics (average and coefficient of variation (CV) over time) of demographic indicators in Italy by time interval.

\begin{tabular}{ccccc}
\hline \multirow{2}{*}{ Variable } & \multicolumn{2}{c}{$\mathbf{1 8 6 2 - 1 9 4 5}$} & \multicolumn{2}{c}{$\mathbf{1 9 4 6 - 2 0 0 9}$} \\
\cline { 2 - 5 } & Mean & CV & Mean & CV \\
\hline GRO & 8.4 & 51.9 & 4.3 & 97.8 \\
SEX & 1.0 & 2.7 & 1.0 & 0.8 \\
BIR & 31.1 & 19.3 & 14.1 & 30.9 \\
DEA & 22.7 & 26.5 & 9.8 & 4.8 \\
MIG & -1.8 & 117 & 0.1 & 2639 \\
NAT & 0.1 & 20.2 & 0.1 & 85.2 \\
STI & 3.5 & 20.5 & 1.4 & 74.6 \\
BRI & 3.7 & 8.8 & 3.3 & 10.5 \\
MAR & 1.4 & 19.6 & 1.3 & 22.1 \\
SPO & 29.4 & 2.5 & 29.5 & 6.1 \\
AGE & 60.1 & 9.7 & 72.4 & 4.1 \\
MER & 1.0 & 2.4 & 1.1 & 1.8 \\
INF & 3.9 & 23.5 & 0.6 & 107 \\
POP & 4.5 & 1.5 & 4.7 & 0.7 \\
URB & 72.9 & 2.0 & 86.2 & 6.4 \\
\hline
\end{tabular}

\subsection{Multivariate Analysis}

A Principal Component Analysis was carried out on the data matrix constituted of demographic indicators, evidencing similar temporal trends and linkages between the most relevant indicators. As shown in Table 2, the first two components accounted for a cumulated variance larger than $80 \%$, summarizing peculiar time patterns for each analysis' dimension, and the indicators contributing the most to such trends. 
Table 2. Indicators' loadings to selected principal components (see Figure 3); bold indicates relevant loadings $>|0.5|$; * indicates a supplementary variable.

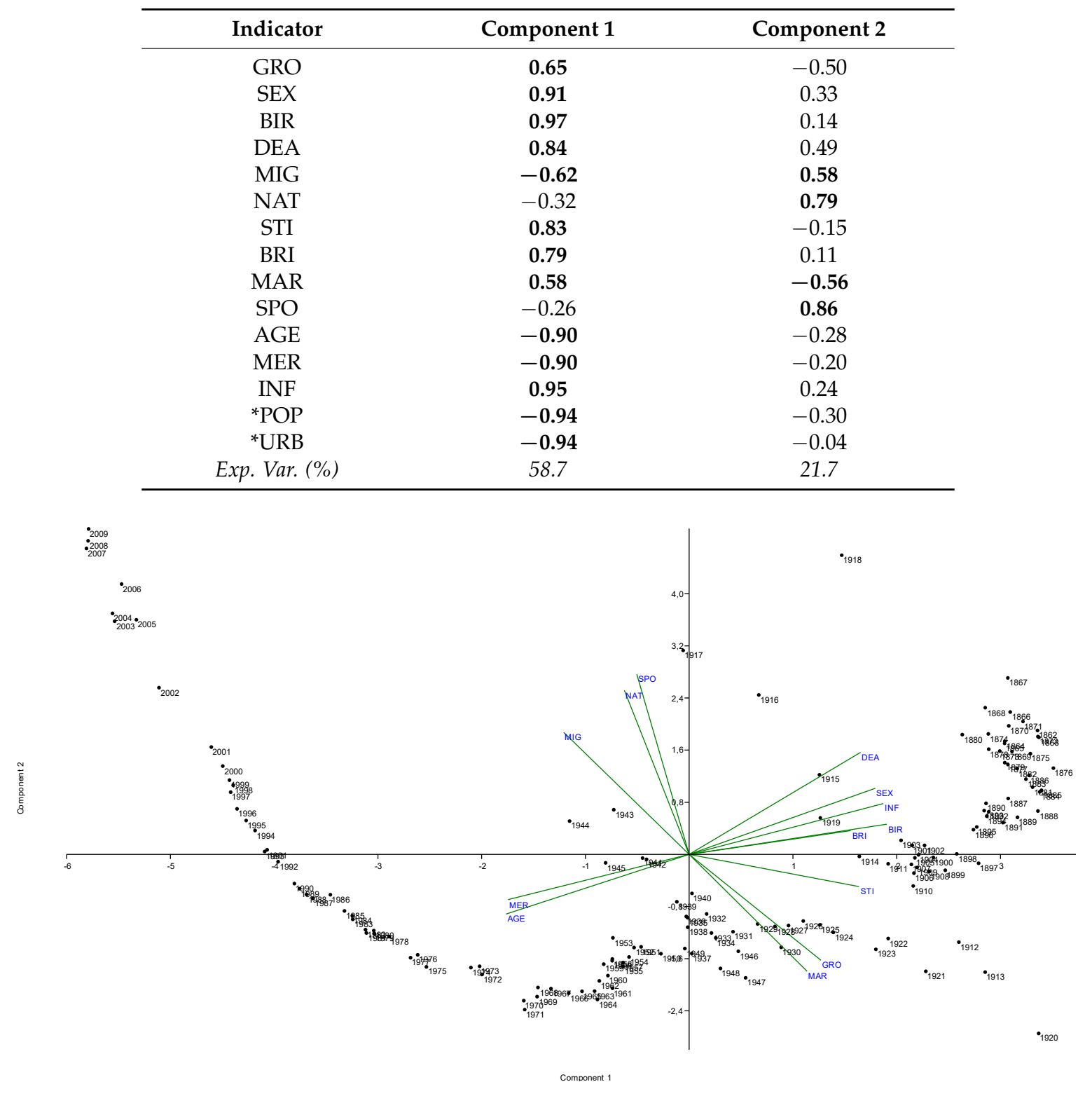

Figure 3. Biplot illustrating loadings and scores to principal components (see Table 1).

Component 1 was correlated with the natural balance (the interplay between birth and death rates), with influence on the age structure of the Italian population. This axis may satisfactorily describe long-term population patterns and relevant consequences of the DT in Italy. As shown in Figure 3, Component 2 was associated with the migratory balance and vital statistics directly influenced by social change, including marriage rate and children out of marriage, and may provide a more dynamic description of social 'modernization' trends in Italy, specifically referring to short- and medium-term trends observed in the aftermath of World War II.

A hierarchical clustering was finally run on the same data matrix with the aim to identify similar trends over time in demographic indicators, as shown in Figure 4. The empirical analysis identifies two clusters that discriminate indicators assessing vital statistics (births and deaths) from indicators quantifying population structure by age, migration, and marriage trends and more recent demographic phenomena (e.g., children out of marriage). This last group displays similarities with both urbanization rates and total population. These results complement the empirical findings presented 
above, distinguishing long-term trends in the natural component of demographic balance and more volatile (and recent) trends influenced by socioeconomic change at global and local scales.

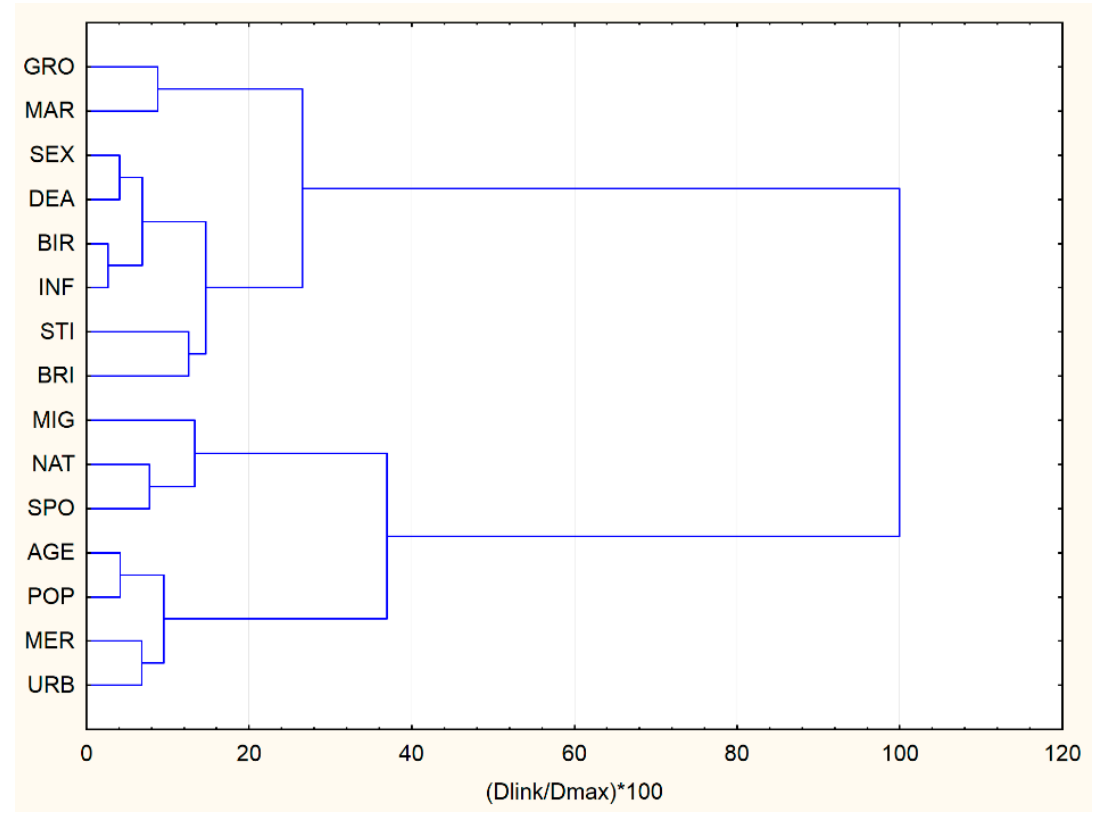

Figure 4. Hierarchical clustering of population indicators during the Italian demographic transition, 1862-2009.

\section{Discussion}

Modernization was considered a process of change towards new types of social, economic, and political systems that have developed and consolidated in economically-advanced countries, especially in Western Europe and North America, over a relatively long time period (17th-19th century), spreading (more or less) rapidly to other countries [8,10,34]. In this framework, the present study explores and clarifies the empirical linkages between population indicators along a complete demographic transition in Italy, defining homogeneous time periods and breakdowns according to the dominant socioeconomic context and possibly reflecting different 'modernization' stages. The results of this work provide an overview of the long transition toward modernization in Italy, focusing on the interplay between demographic patterns and processes [35-39]. At the same time, our study contributes to the analysis of DTs by adopting a wide set of yearly-based indicators that reflect different demographic patterns and processes over a sufficiently long-time span. Being grounded on multivariate exploratory statistical techniques, our approach provides a conceptual and operational perspective to understand demographic trends at country and regional scales, with a special focus on past and present pre-modern societies and their transition to 'Westernized' patterns of economic growth and change in socio-political structures and cultural/institutional organizations.

Advanced economies have shown a turning point from traditional to advanced economic systems in the years between the two World Wars, reflecting a transitional period that coincides with rapid population changes [19]. Although being characterized by a relatively large spatial variability across countries and regions [40-42], an improved characterization of this transitional period sheds light on the relationship between demographic and socioeconomic transitions. The strength of such a linkage is increasingly dependent on rapidly-changing socioeconomic contexts typical of advanced economies [2,43-45]. In these regards, the empirical findings of this study corroborate earlier evidence supporting the assumption that sequential demographic transformations are associated with a broad spectrum of socioeconomic processes driven by industrialization and urbanization $[9,35-39,45]$. Involving multiple dimensions that are difficult to identify and indeed acting as synergistic drivers of change, the interplay between demographic transitions and socioeconomic development is particularly 
relevant in economically-advanced countries. While this study focused on a long period covering 160 years of Italian development, a comparable investigation can be extended to other countries in Southern Europe (such as Spain, Portugal or Greece), with the aim to identify common trends and specific demographic processes, under the assumption that changes in fertility and mortality rates are responsible for distinctive trends of population increase or loss [46]. Mechanisms through which socioeconomic development has influenced fertility rates in recent times include the effects of economic uncertainty [47], job instability [48], unemployment [49-51], volatility in housing markets and mortgage foreclosures [52]. These processes frequently resulted in marriage postponement [53] and declining marriage rates [30,54-58].

Our findings definitely highlight the importance of integrated assessment frameworks in evaluating economic and socio-demographic issues jointly. In this regard, demographic transitions in Italy were observed from a 'co-evolutionary' perspective, identifying distinct components of transition (long-term changes in vital statistics and short-term transformations in migratory patterns, in turn linked with important changes in marriage behavior). Implying an intense interplay between demographic and economic systems [59,60], co-evolution has been known as a main outline for understanding alteration in multifaceted systems [59,61-64], including biological [65,66], social [34,67-76], gene-culture [77], bio-social [78], and socio-ecological structures [79,80]. A comprehensive analysis of population trends in Italy contributes to identify homogeneous time intervals as progressive developmental waves featuring distinct demographic dynamics [18]. These time spans represent conditions of dynamic equilibrium between environmental and socioeconomic contexts [36,39]. Demographic dynamics have indirectly influenced these transitions, e.g., polarizing population distribution in high-density and low-density settlements and leaving large areas of the country under marginal economic conditions, low accessibility, and unbalanced demographic structures because of aging [40-44]. Based on these premises, our study confirms the interpretative framework grounded on the demographic transition theory, identifying distinct components of transition in Italy that outline the intimate relationship between historical development trends and long-term demographic dynamics.

\section{Conclusions}

The approach proposed in this study allows identification of demographic patterns and processes while considering the evolving socioeconomic context over time [77-79]. Multivariate statistical techniques are used to examine long-term population dynamics in Italy during the study period, identifying the most relevant dimensions of Italy's demographic transition. Empirical results of this study document a long period of demographic stability in Italy, with two primary turning points of population dynamics. While one is marked by the time window of the two World Wars, the other one is at the beginning of the 1970s. More specifically, the 1930s and the 1940s were identified as a time interval with a particularly evident turning point in demographic dynamics, as distinctive groups of indicators characterizing pre-transitional, transitional, and post-transitional developmental phases clearly outline. An explicit analysis of diachronic processes (demographic transition and socioeconomic development) allows a more comprehensive investigation of the rapidly-transforming socioeconomic context at the base of 'modernization' stages, providing a knowledge base that may advance strategies of sustainable development oriented toward more balanced socio-environmental complex systems.

Author Contributions: Conceptualization, M.C. and L.S.; methodology, L.S.; validation, M.C., P.S., L.S. and I.Z.; formal analysis, I.Z.; investigation, M.C., P.S., L.S. and I.Z.; data curation, L.S.; writing—original draft preparation, L.S. and I.Z.; funding acquisition, M.C. and L.S.

Funding: This research has been partly financed with funding from the project 'CRISIS', Sapienza University of Rome.

Conflicts of Interest: The authors declare no conflict of interest. 


\section{References}

1. Karamesouti, M.; Detsis, V.; Kounalaki, A.; Vasiliou, P.; Salvati, L.; Kosmas, C. Land-use and land degradation processes affecting soil resources: Evidence from a traditional Mediterranean cropland (Greece). Catena 2015, 132, 45-55. [CrossRef]

2. Serra, P.; Vera, A.; Tulla, A.F.; Salvati, L. Beyond urban-rural dichotomy: Exploring socioeconomic and land-use processes of change in Spain (1991-2011). Appl. Geogr. 2014, 55, 71-81. [CrossRef]

3. Mavrakis, A.; Papavasileiou, C.; Salvati, L. Towards (Un)sustainable Urban Growth? Climate aridity, land-use changes and local communities in the industrial area of Thriasio Plain, Greece. J. Arid Environ. 2015, 121, 1-6. [CrossRef]

4. Zitti, M.; Ferrara, C.; Perini, L.; Carlucci, M.; Salvati, L. Long-term Urban Growth and Land-use Efficiency in Southern Europe: Implications for Sustainable Land Management. Sustainability 2015, 7, 3359-3385. [CrossRef]

5. Salvati, L.; Gargiulo, V.; Rontos, K.; Sabbi, A. Latent Exurban Development: City Expansion Along the Rural-To-Urban Gradient in Growing and Declining Regions of Southern Europe. Urban Geogr. 2013, 34, 376-394. [CrossRef]

6. Salvati, L.; Zitti, M.; Ceccarelli, T. Integrating economic and environmental indicators in the assessment of desertification risk: A case study. Appl. Ecol. Environ. Res. 2008, 6, 129-138. [CrossRef]

7. Salvati, L.; Zitti, M.; Perini, L. Fifty years on: Long-term patterns of land sensitivity to desertification in Italy. Land Degrad. Dev. 2016, 27, 97-107. [CrossRef]

8. Lerner, D. The Passing of Traditional Society: Modernizing the Middle East; The Free Press: Glencoe, UK, 1958.

9. Duvernoy, I.; Zambon, I.; Sateriano, A.; Salvati, L. Pictures from the Other Side of the Fringe: Urban Growth and Peri-urban Agriculture in a Post-industrial City (Toulouse, France). J. Rural Stud. 2018, 57, 25-35. [CrossRef]

10. Harrison, D. The Sociology of Modernization and Development; Unwin Hyman: London, UK, 1988.

11. Levy, M., Jr. Modernization and the Structures of Societies; Princeton University Press: Princeton, NJ, USA, 1966.

12. Khan, J.S. Modernity and Exclusion; Sage: London, UK, 2001.

13. Giddens, A. Modernity and Self-Identity; Self and Society in the Late Modern Age; Polity Press: Cambridge, UK, 1991.

14. Inglehart, R.; Welzel, C. Modernization, Cultural Change and Democracy: The Human Development Sequence; Cambridge University Press: New York, NY, USA, 2005.

15. Parsons, T. The Social System; Free Press: New York, NY, USA, 1951.

16. Chesnais, J.-C. The Demographic Transition: Stages, Patterns, and Economic Implications: A Longitudinal Study of Sixty-Seven Countries Covering the Period 1720-1984; Oxford University Press: Oxford, UK, 1993.

17. Dudley, K. The Demographic Transition. Popul. Stud. 1996, 50, 361-387.

18. Myrskyla, M.; Kohler, H.-P.; Billari, F. Advances in development reverse fertility declines. Nature 2009, 460, 741-743. [CrossRef]

19. Baudelle, G.; Olivier, D. Changement Global, Mondialisation et Modèle De Transition Démographique: Réflexion sur une exception française parmi les pays développés. Historiens et Géographes 2006, 98, 177-204. (In French)

20. Walford, N.; Kurek, S. Outworking of the Second Demographic Transition: National Trends and Regional Patterns of Fertility Change in Poland, and England and Wales, 2002-2012. Popul. Space Place 2016, 22, 508-525. [CrossRef]

21. Ogden, P.E.; Hall, R. Households, reurbanisation and the rise of living alone in the principal French cities 1975-1990. Urban Stud. 2000, 37, 367-390. [CrossRef]

22. Cherlin, A.; Cumberworth, E.; Morgan, S.P.; Wimer, C. The effects of the Great Recession on family structure and fertility. Ann. Am. Acad. Political Soc. Sci. 2013, 650, 214-231. [CrossRef]

23. Valkonen, T.; Martikainen, P.; Jalovaara, M.; Koskinen, S.; Martelin, T.; Mäkelä, P. Changes in socioeconomic inequalities in mortality during an economic boom and recession among middle-aged men and women in Finland. Eur. J. Public Health 2000, 10, 274-280. [CrossRef]

24. Lusardi, A.; Schneider, D.; Tufano, P. The economic crisis and medical care use: Comparative evidence from five high-income countries. Soc. Sci. Q. 2015, 96, 202-213. [CrossRef] 
25. Saurina, C.; Bragulat, B.; Saez, M.; López-Casasnovas, G. A conditional model for estimating the increase in suicides associated with the 2008-2010 economic recession in England. J. Epidemiol. Community Health 2013. [CrossRef]

26. Luo, F.; Florence, C.S.; Quispe-Agnoli, M.; Ouyang, L.; Crosby, A.E. Impact of business cycles on US suicide rates, 1928-2007. Am. J. Public Health 2011, 101, 1139-1146. [CrossRef]

27. Harte, J. Human population as a dynamic factor in environmental degradation. Popul. Environ. 2007, 28, 223-236. [CrossRef]

28. Istat. Atlante Statistico Dei Comuni; Istituto Nazionale di Statistica: Roma, Italy, 2006.

29. Billari, F.C.; Kohler, H.-P.; Andersson, G.; Lundström, H. Approaching the limit: Long-term trends in late and very late fertility. Popul. Dev. Rev. 2007, 33, 149-170. [CrossRef]

30. Caltabiano, M.; Castiglioni, M.; Rosina, A. Lowest-low fertility: Signs of a recovery in Italy? Demogr. Res. 2009, 21, 681-718. [CrossRef]

31. Salvati, L.; Zitti, M. Land degradation in the Mediterranean basin: Linking bio-physical and economic factors into an ecological perspective. Biota 2005, 5, 67-77.

32. Colantoni, A.; Ferrara, C.; Perini, L.; Salvati, L. Assessing Trends in Climate Aridity and Vulnerability to Soil Degradation in Italy. Ecol. Indic. 2015, 48, 599-604. [CrossRef]

33. Ferrara, C.; Carlucci, M.; Grigoriadis, S.; Corona, P.; Salvati, L. A comprehensive insight into the geography of forest cover in Italy: Exploring the importance of socioeconomic local contexts. For. Policy Econ. 2017, 75, 12-22. [CrossRef]

34. Lewin, A.Y.; Volberda, H.W. Prolegomena on coevolution: A framework for research on strategy and new organizational forms. Organ. Sci. 1999, 10, 519-534. [CrossRef]

35. Biasi, R.; Colantoni, A.; Ferrara, C.; Ranalli, F.; Salvati, L. In-between Sprawl and Fires: Long-term Forest Expansion and Settlement Dynamics at the Wildland-Urban Interface in Rome, Italy. Int. J. Sustain. Dev. World Ecol. 2015, 22, 467-475. [CrossRef]

36. Colantoni, A.; Mavrakis, A.; Sorgi, T.; Salvati, L. Towards a 'polycentric' landscape? Reconnecting fragments into an integrated network of coastal forests in Rome. Rendiconti Accademia Nazionale dei Lincei 2015, 26, 615-624. [CrossRef]

37. Ferrara, A.; Kelly, C.; Wilson, G.; Nolè, A.; Mancino, G.; Bajocco, S.; Salvati, L. Shaping the role of 'fast' and 'slow' drivers of change in forest-shrubland socio-ecological systems. J. Environ. Manag. 2016, 169, 155-166. [CrossRef]

38. Kelly, C.; Ferrara, A.; Wilson, G.A.; Ripullone, F.; Nolè, A.; Harmer, N.; Salvati, L. Community resilience and land degradation in forest and shrubland socio-ecological systems: Evidence from Gorgoglione, Basilicata, Italy. Land Use Policy 2015, 1146, 11-20. [CrossRef]

39. Recanatesi, F.; Clemente, M.; Grigoriadis, S.; Ranalli, F.; Zitti, M.; Salvati, L. A fifty-years sustainability assessment of Italian Agro-forest Districts. Sustainability 2016, 8, 32. [CrossRef]

40. Di Feliciantonio, C.; Salvati, L. 'Southern' alternatives of urban diffusion: Investigating settlement characteristics and socioeconomic patterns in three Mediterranean regions. Tijdschrift voor Economische en Sociale Geografie 2015, 106, 453-470. [CrossRef]

41. Salvati, L. Agro-forest landscape and the 'fringe' city: A multivariate assessment of land-use changes in a sprawling region and implications for planning. Sci. Total Environ. 2014, 490, 715-723. [CrossRef] [PubMed]

42. Zambon, I.; Serra, P.; Sauri, D.; Carlucci, M.; Salvati, L. Beyond the 'Mediterranean City': Socioeconomic Disparities and Urban Sprawl in three Southern European Cities. Geographiska Annaler B 2017, 99, $319-337$. [CrossRef]

43. Zambon, I.; Benedetti, A.; Ferrara, C.; Salvati, L. Soil Matters? A Multivariate Analysis of Socioeconomic Constraints to Urban Expansion in Mediterranean Europe. Ecol. Econ. 2018, 146, 173-183. [CrossRef]

44. Zambon, I.; Colantoni, A.; Cecchini, M.; Mosconi, E.M. Rethinking sustainability within the viticulture realities integrating economy, landscape and energy. Sustainability 2018, 10, 320. [CrossRef]

45. Carlucci, M.; Grigoriadis, E.; Rontos, K.; Salvati, L. Revisiting a Hegemonic Concept: Long-term 'Mediterranean Urbanization' in between city re-polarization and metropolitan decline. Appl. Spat. Anal. Policy 2017, 10, 347-362. [CrossRef]

46. Caldwell, J.C. Demographic Transition Theory; Springer: Berlin, Germany, 2006.

47. Hofmann, B.; Hohmeyer, K. Perceived economic uncertainty and fertility: Evidence from a labor market reform. J. Marriage Fam. 2013, 75, 503-521. [CrossRef] 
48. Modena, F.; Rondinelli, C.; Sabatini, F. Economic insecurity and fertility intentions: The case of Italy. Rev. Income Wealth 2014, 60, S233-S255. [CrossRef]

49. Vignoli, D.; Drefahl, S.; De Santis, G. Whose job instability affects the likelihood of becoming a parent in Italy? A tale of two partners. Demogr. Res. 2012, 26, 42-62. [CrossRef]

50. Cazzola, A.; Pasquini, L.; Angeli, A. The relationship between unemployment and fertility in Italy: A time-series analysis. Demogr. Res. 2016, 34, 1-38. [CrossRef]

51. Tragaki, A.; Bagavos, C. Male fertility in Greece: Trends and differentials by educational level and employment status. Demogr. Res. 2014, 31, 137-160. [CrossRef]

52. Schneider, D. The Great Recession, fertility, and uncertainty: Evidence from the United States. J. Marriage Fam. 2015, 77, 1144-1156. [CrossRef]

53. Goldstein, J.; Kreyenfeld, M.; Jasilioniene, A.; Örsal, D.D.K. Fertility reactions to the "Great Recession" in Europe: Recent evidence from order-specific data. Demogr. Res. 2013, 29, 85-104. [CrossRef]

54. Kreyenfeld, M.; Andersson, G.; Pailhé, A. Economic uncertainty and family dynamics in Europe: Introduction. Demogr. Res. 2012, 27, 835-852. [CrossRef]

55. Lee, K.O.; Painter, G. What happens to household formation in a recession? J. Urban Econ. 2013, 76, 93-109. [CrossRef]

56. Ciganda, D. Unstable work histories and fertility in France: An adaptation of sequence complexity measures to employment trajectories. Demogr. Res. 2015, 32, 843-876. [CrossRef]

57. Del Bono, E.; Weber, A.; Winter-Ebmer, R. Fertility and economic instability: The role of unemployment and job displacement. J. Popul. Econ. 2015, 28, 46-479.

58. Sobotka, T.; Skirbekk, V.; Philipov, D. Economic Recession and Fertility in the Developed World. Popul. Dev. Rev. 2011, 37, 267-306. [CrossRef]

59. Kallis, G.; Norgaard, R.B. Coevolutionary ecological economics. Ecol. Econ. 2010, 69, 690-699. [CrossRef]

60. Kallis, G. Socio-environmental coevolution: Towards an analytical approach. Int. J. Sustain. Dev. World Ecol. 2007, 14, 9-19. [CrossRef]

61. Folke, C.; Hahn, T.; Olsson, P.; Norberg, J. Adaptive governance of social-ecological systems. Annu. Rev. Environ. Resour. 2005, 30, 441-473. [CrossRef]

62. Gowdy, J.M. The social context of natural capital: The social limits to sustainable development. Int. J. Soc. Econ. 1994, 21, 43-55. [CrossRef]

63. Costanza, R.; d'Arge, R.; De Groot, R.; Farber, S.; Grasso, M.; Hannon, B.; Raskin, R.G. The value of the world's ecosystem services and natural capital. Nature 1997, 387, 253. [CrossRef]

64. Spash, C. The development of environmental thinking in economics. Environ. Values 1999, 8, $413-435$. [CrossRef]

65. Ehrlich, P.R.; Raven, P.H. Butterflies and plants: A study in coevolution. Evolution 1964, 18, $586-608$. [CrossRef]

66. Thompson, J.N. The Geographic Mosaic of Coevolution; University of Chicago Press: Chicago, IL, USA, 2005.

67. Nelson, R.R. Bringing institutions into evolutionary growth theory. J. Evolut. Econ. 2002, 12, 17-28. [CrossRef]

68. Murmann, J.P.M. Knowledge and Competitive Advantage. The Coevolution of Firms, Technology and National Institutions; Cambridge University Press: Cambridge, UK, 2003.

69. Van den Bergh, J.C.J.M.; Stagl, S. Coevolution of economic behavior and institutions: Towards a theory of institutional change. J. Evolut. Econ. 2003, 13, 289-317. [CrossRef]

70. Safarzynska, K.; van den Bergh, J.C.J.M. Demand-supply coevolution with multiple increasing returns: Policy analysis for unlocking and system transitions. Technol. Forecast. Soc. Chang. 2010, 77, $297-317$. [CrossRef]

71. Janssen, M.A.; Jager, W. Stimulating diffusion of green products. Coevolution between rms and producers. J. Evolut. Econ. 2008, 12, 283-306. [CrossRef]

72. Saint Jean, M. Coevolution of suppliers and users through an evolutionary modelling. The case of environmental innovations. Eur. J. Econ. Soc. Syst. 2005, 18, 255-284.

73. Windrum, P.; Ciarli, T.; Birchenhall, C. Consumer heterogeneity and the development of environmentally friendly technologies. Technol. Forecast. Soc. Chang. 2009, 76, 533-551. [CrossRef]

74. Porter, T.B. Coevolution as a research framework for organizations and the natural environment. Organ. Environ. 2006, 19, 479-504. [CrossRef] 
75. Baum, J.A.C.; Singh, J.V. Organization-Environment Coevolution. In Evolutionary Dynamics of Organizations; Baum, J.A.C., Singh, J.V., Eds.; Oxford University Press: New York, NY, USA, 1994; pp. 379-402.

76. Ward, H. The co-evolution of regimes of accumulation and patterns of rule: State autonomy and the possibility of functional responses to crisis. New Political Econ. 2003, 8, 179-202. [CrossRef]

77. Durham, W.H. Coevolution: Genes, Culture, and Human Diversity; Stanford University Press: Stanford, CA, USA, 1991.

78. Noailly, J.; van den Bergh, J.C.J.M.; Withagen, C.A. Evolution of harvesting strategies: Replicator and resource dynamics. J. Evolut. Econ. 2003, 13, 183-200. [CrossRef]

79. Norgaard, R.B. Development Betrayed: The End of Progress and a Coevolutionary Revisioning of the Future; Routledge: Oxfordshire, UK, 1994.

80. Unruh, G.C. Understanding carbon lock-in. Energy Policy 2000, 28, 817-830. [CrossRef]

(C) 2019 by the authors. Licensee MDPI, Basel, Switzerland. This article is an open access article distributed under the terms and conditions of the Creative Commons Attribution (CC BY) license (http://creativecommons.org/licenses/by/4.0/). 